\title{
A edição e a diagramação da Triogia Cuiabana como álbum de recortes: um exercicio relacional da memoria
}

\author{
The edition and layout of the Trilogia Cuiabana as a scrapbook: \\ a relational memorial exercise
}

Vinícius Pereira

UFMT

DOI: $h t t p: / / d x$. doi.org/10.5902/2176148529979

Resumo: Em Trilogia Cuiabana, destacam-se fragmentos poéticos da Cuiabá da infância do escritor Silva Freire. O efeito estético da Trilogia reside, porém, não só nos textos verbais que a integram, mas também na afetuosa edição e diagramação realizada por Wlademir Dias-Pino. As intervenções desse artista transformaram a obra em um mosaico de poemas, fotos, fragmentos de notícias, gravuras e desenhos. Nesse contexto, o presente artigo visa entender como os cortes, colagens e montagens de Dias-Pino, nos processos editoriais da Trilogia Cuiabana, ressignificam, à guisa de álbum de recortes, as lembranças poéticas de seu amigo Silva Freire, em exercício relacional da memória.

Palavras-chave: Edição. Diagramação. Álbum de recortes. Silva Freire. Wlademir DiasPino.

Abstract: In Trilogia Cuiabana, poetic fragments of the Cuiabá from Silva Freire's childhood abound. However, the aesthetic effects of the Trilogia rely not only on its verbal texts, but also on the affectionate edition and design done by Wlademir Dias-Pino. The interventions by this artist changed the work into a mosaic of poems, photos, pieces of news, prints and drawings. Therefore, this study is aimed at understanding how DiasPino's cuttings, pastings and assemblages ascribed new meanings to Silva Freire's poetic memories as a scrapbook, in a relational memorial exercise, in the editing of the Trilogia Cuiabana.

Keywords: Editing. Design. Scrapbook. Silva Freire. Wlademir Dias-Pino. 


\section{Introdução}

A memória é uma história que não se conta em ordem lógica: sua tessitura é sempre esgarçada, fragmentada, imaginada. Compõe-se de lampejos, equívocos, contradições, lacunas e obsessões. Sua afinidade com a literatura - espaço do verossímil, mais do que da verdade - já foi tematizada sob diversos enfoques epistemológicos, da psicanálise ao marxismo, da hermenêutica aos estudos culturais.

No entanto, a despeito das empreitadas explicativas e indutivas das mais variadas correntes críticas, partindo de textos particulares para Vinícius formulação de parâmetros analíticos algo generalizantes, resta semPereira pre algo de inassimilável e único em cada discurso memorialístico, não apropriável por qualquer pensamento macrossistêmico. Proveniente de uma sobreterminação de variados feixes relacionais - entre o eu e o mundo, entre o eu e a imagem do eu, entre o eu e a linguagem -, toda memória se constrói nesse encontro entre as instâncias do real, do imaginário e do simbólico (LACAN, 1974-1975) e precisa ser vista como um nó - borromeano ou górdio, como queira a teoria - que não se desata.

Relacional que é, a memória só pode ser estudada como tal, pois as lembranças de um sujeito, quando enunciadas, tornam-se parte do repertório de imagens do interlocutor que as escuta ou lê, transformando-as na interação com seu próprio museu imaginário íntimo. A memória é feita de lembranças de outras lembranças, do eu e de outrem, em cadeia impermanente de significantes que impede o rememorado de se encapsular de um sentido último. Afinal, permeando essa tessitura de reminiscências está o poder do olvido, que edita o discurso do passado e impõe, sobre o que foi, o que parece que foi.

Esse texto fragmentário e colidente, feito de vacilantes entrechos mnêmicos, é aquele sobre que se constroem as mais variadas narrativas identitárias, a partir das quais o sujeito se reconhece e se enuncia como “eu". Por vezes, porém, as imagens particulares desse discurso se alçam a dimensões líricas com que se podem identificar outros homens, na medida em que são transpostas esteticamente para um suporte como o da escrita. Isto fez Benedito Sant'Ana da Silva Freire - ou só Silva Freire, como ficou conhecido na posteridade - em uma obra poética que evoca, no final do século XX, memórias pessoais e coletivas em visceral relação com a Cuiabá de antanho: a Trilogia Cuiabana. Segundo Epaminondas Magalhães (2014, p. 168), 
[e]m Trilogia Cuiabana, Silva Freire revela uma cidade de seus tempos de infância, das brincadeiras entre amigos, da boemia. Um passado baseado em ações cotidianas, o que se consolida à medida que, singularmente, o autor reconstrói a realidade, pondo-a em contato com o presente. Nesse contato com o presente, o passado se reconstrói de outra maneira, permeado pela evolução imagética do indivíduo que poetiza essas lembranças. o que aparece nos poemas, desse modo, não é uma cidade, mas um lugar recriado, uma cidade que vive, que pulsa lentamente no frenético progresso que avançava no Brasil.

A edição e a diagramação da Trilogia Cuiabana como álbum de recortes: um exercício relacional da memória

Tanto no plano do enunciado quanto no da enunciação, a obra se 99 afirma como exercício memorialístico. Se sua unidade temática é composta por lembranças da Cuiabá da primeira metade do século XX, a Trilogia Cuiabana não escapou aos caprichos da memória e do esquecimento sequer no processo de publicação. Não obstante o substantivo "trilogia" no título, apenas dois volumes foram impressos, após cuidadosa edição e diagramação de Wlademir Dias-Pino, poeta e amigo de Silva Freire: )presença na audiência do tempo( (FREIRE, 1991a) e )na moldura da lembrança( (FREIRE, 1991b). O terceiro volume nunca foi publicado ${ }^{1}$.

Como Silva Freire morreu meses antes do lançamento dos dois títulos, pode ser que o conteúdo do jamais publicado terceiro livro exista hoje somente na memória do organizador Dias-Pino, que, por sua vez, já está em idade avançada. Consequentemente, talvez esse volume não impresso da póstuma Trilogia Cuiabana venha a existir, dentro de alguns anos, apenas como uma memória histórico-crítica da perda de parte da memória poética de Freire. Memória do esquecimento, enfim.

Em contraponto a essa perspectiva de um derradeiro apagamento iminente de parte da memória da Trilogia Cuiabana - o inédito terceiro volume -, o presente artigo pretende um movimento de retorno à Trilogia, mas numa perspectiva ainda pouco explorada pela crítica especializada: o papel desempenhado pela edição e diagramação vanguardista dos dois

1 Ramos (2011) cita duas versões constantes na historiografia literária mato-grossense para a incompletude da Trilogia Cuiabana: alguns afirmam ter havido um furto na sala de trabalho de Dias-Pino, então designer gráfico da Universidade Federal de Mato Grosso, cuja editora publicou a Trilogia Cuiabana; outros dizem que a não publicação teria se dado por motivos econômicos, pois "o custo de edição do volume teria estourado o orçamento e não mais foi possível conseguir novo financiamento” (RAMOS, 2011, p. 158). 
livros como curadoria e coleção da memória de Freire. Para tanto, adota-se aqui a hipótese de leitura de que Wlademir Dias-Pino, ao organizar os dois volumes, debruçou-se sobre as reminiscências escritas do amigo recém-falecido para reelaborar, em uma sintaxe visual, lembranças também suas. Nesse movimento relacional da memória, parece-nos que o poeta-editor-diagramador chegou a transformar o gênero da Trilogia: em vez de livros de poemas, ou antologia poética, Dias-Pino diagramou dois álbuns de recortes ${ }^{2}$, daqueles que revisitamos quando assoma a saudade de um finado ente querido. É, pois, a um similar retorno que o presente arti-

Vinícius

Pereira go convida, a fim de indagar como os processos de edição e diagramação da Trilogia Cuiabana sublinham sua dimensão memorialística, ao configurar visualmente os livros como álbuns de recortes.

Para tanto, na próxima seção adotamos a perspectiva de quem se aproxima do álbum, examinando sua capa e sua organização geral, sobretudo a composição editorial de seus paratextos (GENETTE, 2006). $\mathrm{Na}$ seção seguinte, procedemos a uma incursão mais aprofundada na obra, analisando-se uma seção específica da Trilogia, como amostra das estratégias de edição e diagramação que Dias-Pino usou na coleção e reinterpretação das memórias poéticas do amigo Freire.

\section{Um álbum de recortes no cerrado: aproximando o olhar}

Ainda que possam se apresentar em formatos e temáticas variadas, álbuns em geral partilham uma característica comum que permite identificá-los como gênero discursivo: um princípio de organização por recorte, colagem e montagem, em que a justaposição de elementos constrói um metadiscurso que os unifica, seja por um tema (álbuns sobre a infância, sobre um evento histórico, sobre um lugar), seja pela natureza dos objetos incorporados (álbuns de selos, de fotos, de cromos autocolantes). Segundo Ceia (2010, n. p.), a palavra "álbum" tem origem no latim albus (branco) e significava, entre os romanos,

uma tabuleta branca onde se afixavam os edictos públicos. Mais tarde, a partir do século XVI, o termo passou a designar um livro em branco, destinado a coleccionar autógrafos, versos, pensamentos, fotografias, desenhos, selos, recortes de imprensa, etc.

2 Adota-se, no presente artigo, o termo "álbum de recortes" como tradução aproximada do substantivo inglês scrapbook, designativo de encadernações esteticamente trabalhadas para coleção de textos evocativos de memórias, como fotos, recortes de jornais, papéis avulsos etc. 
(...) Modernamente, a organização de um álbum pode ser feita segundo os mesmos princípios do hipertexto, associando elementos diversificados, embora sem as potencialidades audiovisuais do texto electrónico.

A edição e a

diagramação

da Trilogia

Nesse sentido, um álbum pode ser considerado, na maioria dos Cuiabana casos, uma manifestação textual multimodal para uma empreitada colecionística, em que fragmentos evocativos de um passado se coligem, como álbum de recortes: geralmente por interesses pessoais e/ou afetivos. Ainda que não falasse um exercício especificamente de álbuns, o pensamento de Walter Benjamin sobre a coleção e o colecionador - dinâmicas de que o álbum é uma materialização em gênero discursivo - pode nos ajudar a entender o movimento nostálgico de voltar-se ao passado a partir de um livro de recortes: "Corelacional da memória lecionar é uma forma de recordação prática e de todas as manifestações profanas da 'proximidade', a mais resumida" (BENJAMIN, 2007, p. 239). Assim, a organização dos livros de Freire permitiu uma forma de "recordação prática" a Dias-Pino, que pôde construir um patchwork de poemas do amigo, fotos de Cuiabá, desenhos e gravuras suas, citações de grandes pensadores europeus e mesmo textos não poéticos, como notícias, listas e regimentos. Tal peculiaridade do projeto editorial da Trilogia Cuiabana leva Hilda Magalhães a afirmar que a obra "bem poderia se chamar 'anatomia cuiabana", com um "processo de construção (...) básica e essencialmente intertextual" (MAGALHÃES, 2001, p. 171).

À moda de uma intertextual coleção, os polifônicos fragmentos discursivos verbais e não verbais ressignificam-se mutuamente no contexto do álbum de recortes que é a Trilogia, compondo uma errante tessitura de como Dias-Pino reinterpretava as memórias poéticas de Freire frente a Cuiabá. Não se trata, pois, só das memórias do autor, nem só das memórias do organizador. É em ato relacional que a coleção faz do prosaico único; do pessoal, social; da justaposição, articulação. Nesse processo, Dias-Pino, ao publicar os poemas freireanos em formato similar ao de álbuns de recortes, convida-nos a partilhar com ele e Freire lembranças que se individualizam como flashes poéticos da Cuiabá de outrora, na )moldura da lembrança(, conforme o título do segundo volume da Trilogia indica. Note-se aí que os parênteses virados do avesso, inusitadas marcas gráficas que integram os títulos da Trilogia, sugerem uma suspensão no tempo desse pretérito cujos fragmentos de experiência o livro recolhe, construindo, junto ao leitor de hoje, uma possi- 
bilidade de ponte com o passado: uma )presença na audiência do tempo(. Como é impossível que retornemos à Cuiabá da primeira metade do século XX, Dias-Pino organiza o livro de modo que essas lembranças, como coleção, venham-nos encontrar hoje: "O verdadeiro método de tornar as coisas presentes é representá-las em nosso espaço (e não nos representar no espaço delas). (Assim procede o colecionador e também a anedota)" (BENJAMIN, 2007, p. 240).

Para tanto, desde as capas e contracapas - elementos de papel central no projeto de edição e diagramação de um livro, conferindo no-

Vinícius

Pereira

102 vos sentidos ao texto por meio de paratextos editoriais (GENETTE, 2006) -, os dois volumes da Trilogia Cuiabana (Figuras 1 e 2, respectivamente) já se anunciam como coleções de memórias de Silva Freire.
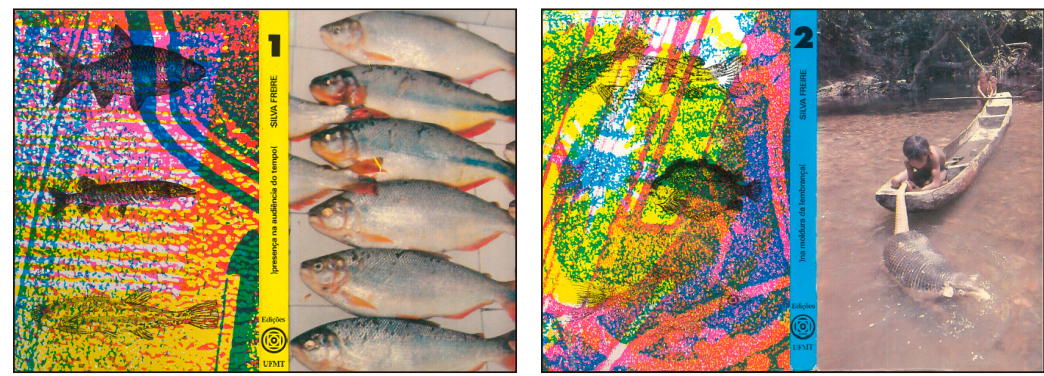

Figuras 1 e 2: Capa e contracapa dos volumes 1 e 2 da Trilogia Cuiabana Fonte: FREIRE (1991a, 1991b)

Na capa do volume 1, observam-se peixes (dourados) dispostos sobre uma superfície branca azulejada, possivelmente um balcão em mercado de pescados; na do volume 2, um grupo de crianças que brincam com uma canoa e um tatu, puxando-lhe o rabo. Ambas as imagens, ao remeterem a aspectos da interação humano-natureza envolvendo espécies de animais endêmicas do Centro-Oeste brasileiro, sugerem que se trata de fotos tiradas nessa região; no entanto, não permitem que se identifique precisamente se foram tiradas em Cuiabá, no seu entorno, ou em localidades mais distantes do Cerrado ou do Pantanal. Tal impossibilidade de definir com exatidão os lugares onde as fotos foram feitas opõe-se significativamente à precisão das espacialidades representadas nos poemas da Trilogia, em que abundam referências explícitas a espaços públicos e privados da capital do estado de Mato Grosso, como se nota no trecho a seguir, retirado do longo poema em prosa "Na topografia de nomes como levantamento de caminhos": 
- Praça da República:

- a Farmácia do Bivar, Biezinho Neves, Loja do Matraca, Comen-

dador José Henrique Vieira, a farmácia de 1923, de seu Rabelo

A edição e a

Leite..., era Filipe Jorge, pai de Chico Jorge, então cartão-de-

-visita impresso na alegria do Hotel Esplanada..., o grande Ade-

lino de Albuquerque e Zé Rabelo ensaiando pesquisas no ninho

de arte secular folclórica, quase na esquina da Loja de Manoel Cuiabano.

diagramação

da Trilogia

Cuiabana

como álbum

de recortes:

- Padre Luiz Sutera, da Sić́lia para o Brasil, e não saiu mais de um exercício Cuiabá...

relacional da

- Loja Laraya, importadora e o primeiro rádio de válvula

memória

na cidade! que invento genial!, como a Livraria Santa The-

rezinha!

03

- o "Bar O Ponto", de seu Moreira, com cadeira cativa do viajan-

te Jorge Parreiras, e a "Renascença", do Braguinha, na freguezia

(sic) sortida de caderneta... (FREIRE, 1991a, p. 97)

Nesse excerto, bastante representativo do estilo adotado nos demais poemas da Trilogia, observa-se uma profusão de substantivos próprios, designativos de lugares em Cuiabá e habitantes da cidade, desde os mais famosos, como um comendador, aos conhecidos só pelos mais próximos, tal qual um dono de bar local. Como o título do poema em prosa sugere, trata-se mesmo de uma topografia de nomes, os quais vão se justapondo na obra para construir um mapa onomástico de uma Cuiabá de tempos idos, conforme o eu-lírico flâneur que Silva Freire faz caminhar das mais largas e populares avenidas aos mais estreitos e íntimos becos da cidade.

A esse excesso de referências espaciotemporais precisas nos poemas, a diagramação de Dias-Pino opõe uma vagueza de elementos dêiticos de tempo e espaço nas fotos de capa, replicando a dialética entre reminiscência e lacuna que cadencia o movimento memorialístico. Se algumas de nossas lembranças nos parecem reais demais, porque permeadas por detalhes contextuais verossímeis, outras são apenas lampejos sem rosto, tempo ou espaço. E o trabalho da memória e do inconsciente acaba por contaminar umas às outras com o passar dos anos, preenchendo lacunas com informações imaginárias e fundindo diferentes reminiscências em uma mesma imagem. 
A falta do título ou do nome do autor ${ }^{3}$ nas capas da Trilogia Cuiabana, elementos básicos da diagramação/edição de livros em geral, reforça o efeito de estranhamento que a obra causa: trata-se de fotos sem texto escrito sobreposto que as explique, tais quais as lembranças que nos falam vivamente aos sentidos, mas não necessariamente à memória verbal. o mesmo padrão é ainda replicado para as fotos que o diagramador incluiu no miolo dos livros, em meio aos poemas de Freire: nenhuma delas vem acompanhada de legenda explicativa na própria página ${ }^{4}$, o que as abre para um processo livre de reinterpreta-

Vinícius

Pereira ção a cada vez que são revisitadas.

A não adição de título ou legenda contíguos às fotos de capa ou às do miolo é operação não só de diagramação, mas também de curadoria da memória de Freire, similar à do curador de museu que opta por não informar quando e onde determinadas fotos em exposição foram tiradas. Segundo Sontag (2005), o efeito desse procedimento é enfatizar a fotografia como produto artístico, mais do que documental. Assim, quando Dias-Pino prepara a Trilogia Cuiabana para publicação, a dimensão estético-afetiva da memória, inclusive a fotográfica, ultrapassa a factual. As fotos da obra funcionam, pois, feito um registro do desejo de ver e reter, mais do que como registro dos objetos vistos. Como num álbum de memórias, tais imagens são ressignificadas pelo contexto em que são coladas, e não definidas pelo espaço-tempo do real fotografado, no que mais uma vez se aproximam da curadoria feita por um colecionador:

\footnotetext{
O mais profundo encantamento do colecionador consiste em inscrever a coisa particular em um círculo mágico no qual ela se imobiliza, enquanto a percorre um último estremecimento (o estremecimento de ser adquirida). Tudo o que é lembrado, pensado, consciente torna-se suporte, pedestal, moldura, fecho de sua posse. (BENJAMIN, 2007, p. 239)
}

\footnotetext{
3 Na Trilogia Cuiabana, tais elementos são informados apenas na lombada, embora os livros sejam encadernados no modelo brochura e capa mole, padrão que quase sempre apresenta títulos na capa. A incomum opção por exibição de títulos apenas na lombada é, por outro lado, menos infrequente em livros cuja encadernação se faz por costura e capa dura imitando couro.

4 Logo após as respectivas folhas de rosto, cada um dos dois volumes apresenta como paratexto uma página com lista de créditos fotográficos, nas quais se apresentam os fotógrafos, os números de página e as legendas das fotos, mas estas não são repetidas quando da apresentação das imagens ao longo da obra.
} 
Ainda no âmbito da diagramação dos paratextos editoriais dos dois livros, a dialética memorialística entre o preciso e o impreciso, entre o factual e o imaginário do álbum de recordações, pode ser vista também nas contracapas de ambos os volumes da Trilogia Cuiabana (Figuras 1 e 2). Em cada uma delas, figuram três peixes reproduzidos graficamente pelo processo de gravura, sobrepostos a composições abstratas das três cores primárias do sistema subtrativo RYB: red, yellow, blue - ou, mais precisamente, no campo editorial, magenta, amarelo e ciano (RIBEIRO, 2003). Se, por um lado, as imagens das contracapas dialogam com as das capas porque apontam para referentes do mesmo campo conceitual (peixes, rio e água), opõem-se a elas na medida em que não se querem representações de cunho realista. Em vez do real inescapável à captação da luz pela fotografia (SONTAG, 2005), tem-se nas contracapas o onirismo de peixes que flutuam em um fluido de cores A edição e a diagramação da Trilogia Cuiabana como álbum de recortes: um exercício relacional da memória inverossímeis. Não se trata, pois, da água de rio de facto, mas sim, do fluxo de memória em que se movem as lembranças poéticas da Cuiabá freireana.

É nesse mesmo fluxo piscoso que, entre os vários textos críticos já publicados sobre a Trilogia Cuiabana, Dias-Pino "pesca" fragmentos para comporem as orelhas dos volumes. Nestas, observam-se a premência de duas metáforas, a do texto-memória e a do texto-catálogo, como, respectivamente, nos dois fragmentos a seguir:

\footnotetext{
Pode ser assim: - esse plúrimo Silva Freire viveu as bibocas (lembranças), rés-do-chão (história), botecos da vida (rememória), ruas do tempo (alturas), e becos azuis... Apenas um passante, deixando a ideia de estar ausente, mas o sabemos Poeta de vanguarda e prosador, inovador, sempre. Por isso, até, se julga no direito de nos dar um soco na cara, bruto e suave ao mesmo tempo, abrindo este livro que nos alicia e entontece, nos alumbra e nos desafia a repensar o extrato social cuiabano que está aí (...)
}

Um livro que começa onde se abre. Cada parte é um livro para o leitor se perder nos envolvimentos catalogados.

Sem autoria claramente expressa e com diagramação de parágrafos com significativo espaçamento gráfico entre si, não há como o leitor saber se cada orelha constitui um texto único, ou um mosaico de diferentes falas sobre os livros. Não é sequer possível, apenas com a leitura das orelhas, atribuir a autoria desses fragmentos, exceto no caso de citações diretas 
Vinícius

Pereira

106

de terceiros. Como os discursos da memória, as orelhas vêm estruturadas por uma parataxe de metáforas anônimas, que ora se complementam, ora se contradizem. De todo modo, como entre elas se destacam os tropos de texto-memória e texto-catálogo, conforme mencionado anteriormente, há que se ver na interseção dessas metáforas a imagem do álbum de recortes. Afinal, tal gênero nada mais é do que um catálogo - lista arbitrária e não exaustiva - das memórias de alguém. No caso da Trilogia, trata-se das memórias de Silva Freire, editadas amorosamente por Dias-Pino, como se nota no afetuoso prefácio ao segundo volume, de texto “ABC do mutirão”.

Aqui, nesta original auto-biografia (alta sinceridade), o autor se confunde em sira com a comunidade. Aparecem, avivando a ideia, um a um, os habitantes, agora, chamados pela forte presença domingueira do nome de nascença, e, principalmente, os tipos populares - há! essa gente de calcanhar sujo - com seus côncavos apelidos, para em grande ciranda irem cantando, até descobrirem, depois de bater os pés no chão até levantar poeira, coisas lendárias que vem (sic) puras do Lugar de Guimarães, impregnadas de mistério. (DIAS-PINO apud FREIRE, 1991b, p. 222)

Avaliada pelo metro do "sincero", e não do "real" ou "verdadeiro", a Trilogia se aproxima, nas palavras de Dias-Pino, de uma "auto-biografia". No entanto, em vez de enfatizar a dimensão discursiva do "eu" enunciativo, ponto-chave para a constituição desse gênero, o autor define a obra como uma sucessão de imagens - e, portanto, de imaginações - da Cuiabá da infância e juventude de Freire, em uma "grande ciranda" de memórias, como bem ilustra qualquer álbum de recortes.

No processo que a Trilogia Cuiabana enseja, as reminiscências passam por um trabalho de reelaboração, em que não são simplesmente "acessadas", como querem os tropos mais maquinais da mente humana. Os habitantes desse passado são "chamados pela forte presença domingueira do nome de nascença" e "pelos côncavos apelidos", o que ressalta o papel da linguagem na construção da memória.

Como o ato de invocar é também o de nomear, isto é, instanciar no plano enunciativo entes do universo extralinguístico, o fato de que os "habitantes" da comunidade são chamados ora pelo nome, ora pelo apelido, não é gratuito. Se aos registros oficiais interessam apenas os nomes civis, um álbum de recortes funciona segundo uma lógica outra: no espa- 
ço do íntimo, a memória é sempre polissêmica, revestindo de diferentes sentidos uma mesma lembrança, ou de diferentes significantes (nome ou apelido) o mesmo referente. Essa dinâmica movediça da memória, no afetuoso álbum que é a Trilogia Cuiabana, está também presente na "grande ciranda" em que Silva Freire chama os nomes e apelidos "até levantar poeira", isto é, até o turvamento que pó e tempo impõem às reminiscências.

Por fim, ainda no âmbito paratextual, também significativa no projeto gráfico-editorial da Trilogia como álbum de recortes é a gravura (Figura 3) com que Dias-Pino ilustrou as páginas ${ }^{5}$ em que o "ABC do mutirão" aparece na obra.

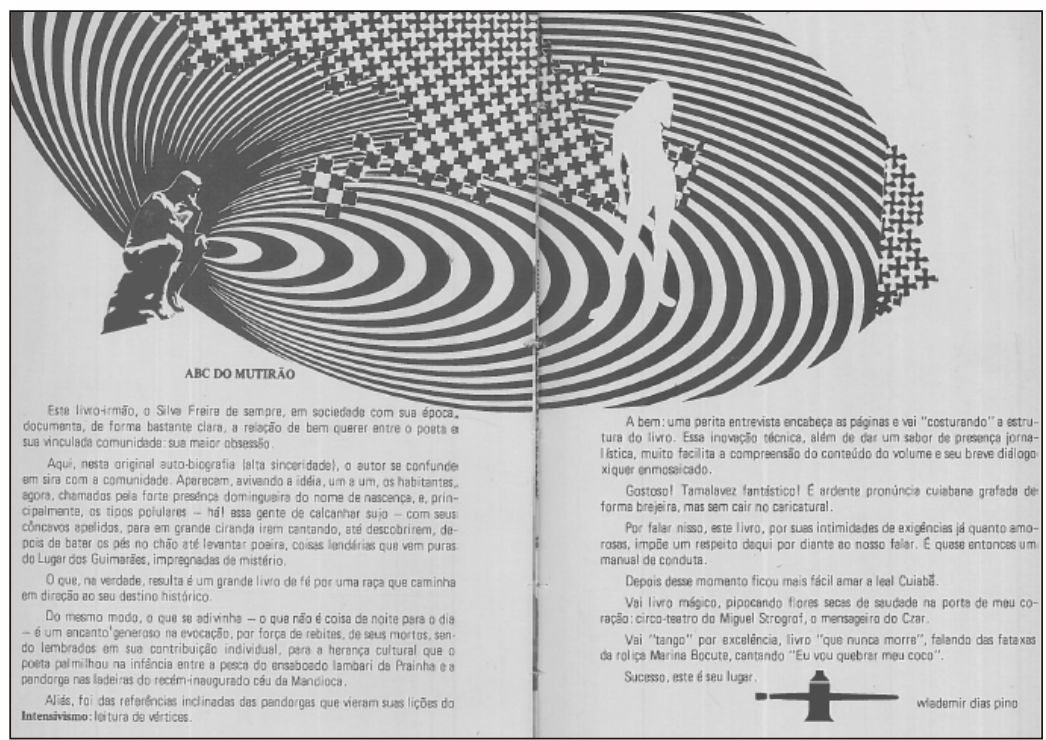

A edição e a diagramação da Trilogia Cuiabana como álbum de recortes: um exercício relacional da memória

Figura 3: Ilustração ao texto "ABC do mutirão"

Fonte: FREIRE (1991b, p. 222-223)

Em um primeiro momento, logo ressalta ao olhar que tal imagem foi cuidadosamente posicionada pelo diagramador de modo a ocupar duas páginas, atravessando o ponto de costura da encadernação e

5 Trata-se das páginas 222 e 223 do segundo volume. Note-se, porém, que ambos os livros seguem uma sequência única de paginação, de modo que o primeiro volume vai da página 1 à 208 , ao passo que o segundo vai da 209 à 416. A continuidade da numeração ressalta a organicidade da Trilogia como álbum de recortes ou coletânea de memórias que não se encerra em um único opúsculo. Por outro lado, a impressão do miolo do primeiro volume em papel amarelo e o do segundo volume em azul impõe certa descontinuidade visual aos livros, como se cada um tivesse sido produzido a partir de colagens de textos em avulsos álbuns de cores diferentes, separadamente comprados ou produzidos. 
indicando um princípio de expansão visual que desrespeita os limites mais óbvios da diagramação. Para simbolizar a memória, que também se dilata para além das balizas do real e do simbólico, embaralhando categorias de espaço, tempo e pessoa, a gravura se compõe de elipses encaixadas umas nas outras, numa onda crescente a partir da figura humana à esquerda. Esta, por sua vez, encontra-se sentada numa posição muito parecida com a do Pensador, de Rodin, ou como um homem que se defronta com suas reminiscências - a partir de um álbum de recortes, talvez. Para tal leitura, ainda mais significativo é o fato de que essa é

Vinícius

Pereira

108 a única imagem com que Wlademir Dias-Pino ilustra o também único texto de sua autoria sobre a Trilogia Cuiabana que consta no miolo de um dos volumes. Nesse diapasão, tanto o texto "ABC do mutirão" quanto a gravura que o acompanha se revelam metassignos na Trilogia, definindo que a obra deve ser lida como colagem de fragmentos memorialísticos.

A sintaxe de corte e colagem, estruturadora do gênero álbum e cara a toda forma de intertextualidade (COMPAGNON, 1996), comparece ainda nessa gravura em outras medidas, especialmente na disposição das elipses e no seu posicionamento em relação aos limites da folha de papel. No caso da padronagem geométrica, note-se que as elipses são ocultadas, em alguns pontos da imagem, por uma segunda composição pictórica, em que se destacam cruzes irregulares, aparentemente coladas sobre os motivos elípticos. Tal superposição de ritmos visuais distintos metaforiza a equivocidade do texto literário, sempre construído numa rede intertextual em que o autor opera, a tesoura e cola, um mosaico de discursos outros. No caso da Trilogia Cuiabana, tal processo se dá em dois níveis distintos - tanto na escritura de Freire, que embaralha textos seus e discursos alheios, quanto na diagramação de Dias-Pino, que recorta e cola uma miríade de imagens, misturando distintas linguagens visuais -, duplicidade sugerida também pela presença de duas figuras humanas na gravura.

Além disso, ao optar por posicionar tal imagem rente à parte superior das folhas de papel, deixando parte da gravura "para fora" do livro, Dias-Pino reproduz o desrespeito à mancha gráfica que caracteriza a arquitetônica de álbuns de recortes. Nesse gênero, as imagens costumam ser coladas com significativa zona de sobreposição entre si e às vezes até deixando escapar rebarbas para além do espaço da página, uma vez que o que preside a justaposição de fragmentos em uma coleção não é uma lógica cartesiana argumentativa, e sim um processo de associação livre, como o que (des)governa a memória. 
Nesse sentido, pode-se até dizer que a memória é algo análoga ao carnaval, na medida em que subverte relações lógicas, sobrepõe eventos, inverte hierarquias e colore de matizes as mais diversas cada uma das reminiscências que o corpo evoca. Basta lembrar, por exemplo, as memórias íntimas de cada um de nós: quantos não temos álbuns com fotos de carnavais antigos, coladas em meio a tíquetes de baile amarelecidos, ou uma flor seca trocada entre mascarados cujo nome ou verdadeira face se perderam no passado?

Tal símile entre carnaval e memória torna-se ainda mais pertinente no contexto da Trilogia Cuiabana se considerarmos que parte significativa dos textos da obra fazem referência ao antigo carnaval na capital de Mato Grosso, e que Silva Freire e Dias-Pino foram muito atuantes na renovação do carnaval cuiabano nas décadas de 70 e 80, inclusive com projetos político-culturais conjuntos.

Diante de tal fato, aliado à impossibilidade de analisar na íntegra, em um artigo como este, as mais de 400 páginas da Trilogia, optamos por fazer a seguir um corte analítico vertical de uma seção específica - com textos verbais e não verbais sobre o carnaval -, em oposição à mirada mais panorâmica até aqui feita sobre os paratextos da obra. Desse modo, realizaremos mais detidamente um close-reading das relações que a diagramação e a edição de Dias-Pino estabelecem com os textos memorialísticos de Freire, na Trilogia Cuiabana, sobre os folguedos da Cuiabá de antanho.

\section{Recortes de folguedos}

As 28 páginas (p. 360-387) do volume 2 da Trilogia Cuiabana que se referem ao carnaval na atual capital de Mato Grosso compõem um núcleo temático claramente delimitado na obra. Na primeira página da seção com tal temática (Figura 4), encontram-se seu título ("Quanto mais não fosse o carnaval") e uma espécie de ementa de conteúdos; todavia, estes não podem ser entendidos como índice nem sumário da seção, uma vez que não apresentam números de páginas, tampouco títulos de subseções ou poemas. 
Vinícius

Pereira

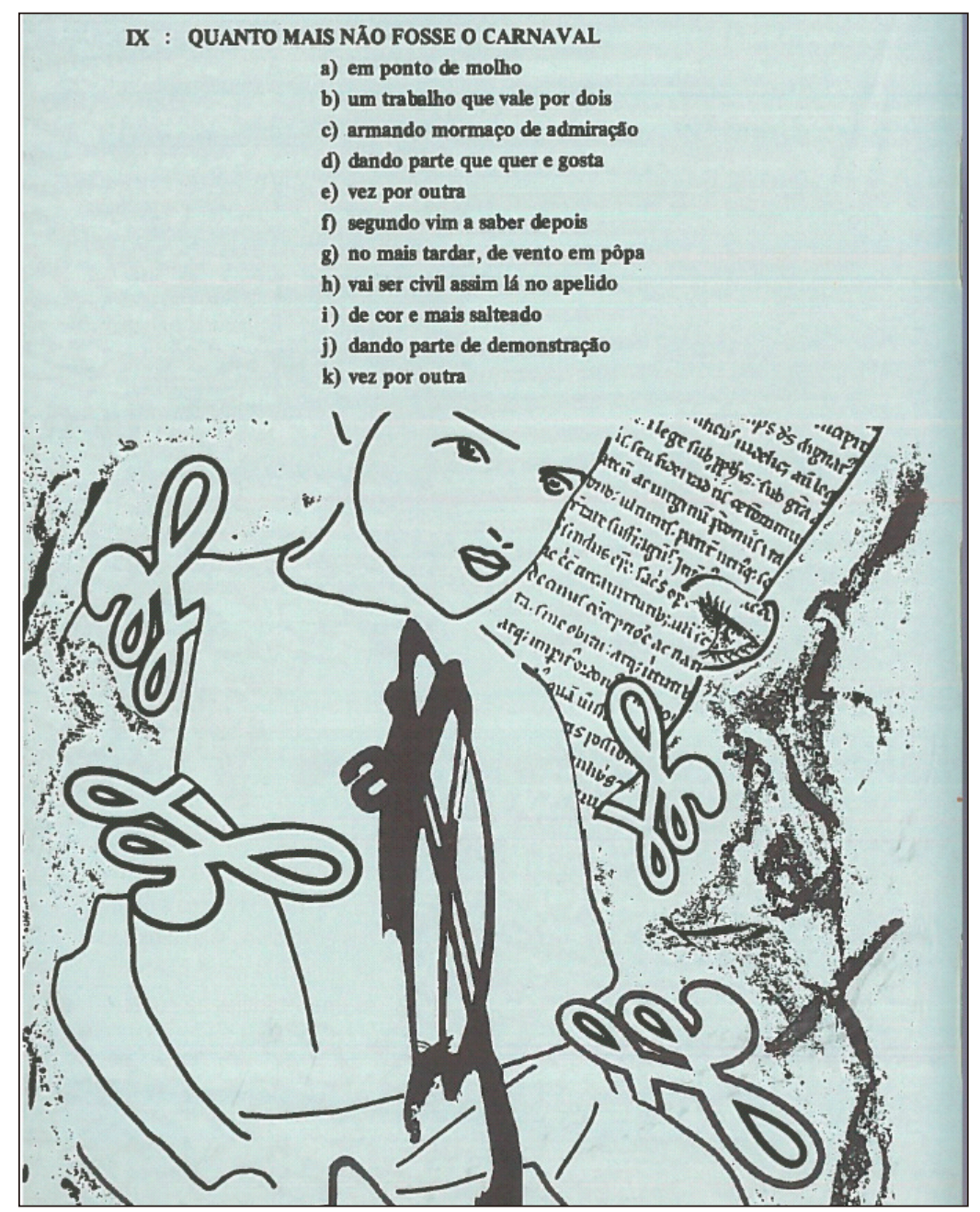

Figura 4: Primeira página da seção sobre carnaval na Trilogia Cuiabana

Fonte: Freire (1991b, p. 360)

A organização dos conteúdos por tópicos na primeira página é uma estrutura adotada por Silva Freire ao longo das demais seções da Trilogia, como aquelas que falam sobre as ruas de Cuiabá, a festa de São Benedito ou a vida dos tipos populares. A parataxe característica dessas listas, traço estilístico constante dos "blocos poemáticos" de Freire (TELES apud FREIRE, 1986, p. 136), é também replicada na maior parte das ilustrações de Dias-Pino constantes no miolo da obra, como se nota na reprodução de desenho em nanquim logo abaixo da ementa na Figura 4. Tal ilustração de mulher - de lábios carnudos e perfil em três-quartos, como a maior parte das demais figuras femininas na obra - integra uma 
colagem junto a vários outros elementos, entre os quais se podem identificar um texto em idioma desconhecido, formas espirais, letras e borrões. Com elementos gráficos que se superpõem, a componente não verbal da página opera uma dinâmica paratática de recorte e colagem que fundamenta, para além do gênero álbum, todo ato intertextual de escrita e leitura, como bem resume Compagnon (1996, p. 11, grifos nossos):

Recorte e colagem são as experiências fundamentais com o papel, das quais a leitura e a escrita não são senão formas derivadas, transitórias, efêmeras. Entre a infância e a senilidade, que terei feito? Terei aprendido a ler e a escrever. Leio e escrevo. Não paro de ler e escrever. E por quê? Não seria pela única razão inconfessável de que, no momento, não posso me dedicar inteiramente ao A edição e a diagramação da Trilogia Cuiabana como álbum de recortes: um exercício relacional da memória jogo de papel que satisfaria o meu desejo? A leitura e a escrita são substitutos desse jogo. Sinto saudade dos livros antigos, do tempo em que era preciso abri-los previamente com o corta-papel.

Sendo o recorte e a colagem operações do desejo e da saudade, como salienta o excerto acima, é no desejo da memória do outro que a Trilogia Cuiabana se compõe, na medida em que Silva Freire reúne, por intertextualidade entre memórias pessoais e coletivas de Cuiabá, imagens de gozo do antigo carnaval na cidade. Por sua vez, é também no desejo de ressignificar essas memórias que Dias-Pino realiza a edição/ diagramação dos volumes, operando um retorno nostálgico a quando a tesoura e cola recortavam bandeirolas, máscaras e serpentinas para o tríduo momesco de Cuiabá.

O jogo de recorte e colagem no âmbito do carnaval materializa-se também nessa seção da Trilogia Cuiabana por meio de uma clipagem de notícias, realizada por Silva Freire a partir de arquivos da mídia impressa local, coligidos "pelo professor Carlos Rosa ${ }^{6}$ e sua mulher, Neuza $^{7 ”}$ (FREIRE, 1991b, p. 364). Sucedem-se, ao longo de algumas páginas da seção, seis recortes de jornais com notícias do carnaval cuiabano no início do século XX, retirados da Gazeta oficial (1902, 1903 e 1904) e dos jornais O estado (1906), A imprensa (1913) e O debate (1914). Tais notas são diagramadas em sequência na obra, mas sem obedecer a uma ordenação

6 Professor da Universidade Federal de Mato Grosso; à época, diretor do Departamento de Cultura e Turismo de Cuiabá e do Carnaval Cuiabano.

7 Neuza Bini Rosa, à época professora do Departamento de História da Universidade Federal de Mato Grosso. 
por periódico, ano ou sequer tema. Foram como que afixadas à página por associação meramente afetiva, em que se destacam, em letras maiúsculas ou negrito, nomes de blocos de rua, foliões famosos ou salões dos idos carnavais cuiabanos.

A apresentação de ideias, fatos e imagens, nessa dinâmica de parataxe cara a álbuns e colagens em geral, reproduz-se ao longo de toda a Trilogia Cuiabana; em outras seções, essas enumerações não exaustivas de fragmentos tomam a forma de poemas com nomes de ruas, pratos típicos, piadas, "causos", compondo um mosaico poético

Vinícius

Pereira da cidade. Segundo esse procedimento, Silva Freire vai coletando flashes e instantes da vida em Cuiabá para, por metonímia, reconstituir a cidade de sua memória, em que as relações criadas pela colagem de fragmentos na Trilogia ampliam as relações que esses mesmos elementos um dia desempenharam no real, mesclando dimensões subjetivas e objetivas da memória. A esse respeito, dissera já Benjamin (2007, p. 241, grifos do autor) que "[t]udo isso, os dados 'objetivos', assim como os outros, forma para o autêntico colecionador em relação a cada uma de suas possessões uma completa enciclopédia mágica, uma ordem do mundo, cujo esboço é o destino de seu objeto". Assim, como Enciclopédia de Cuiabá, a Trilogia não só retextualiza e reordena os discursos da/sobre a cidade, como também postula um destino para Cuiabá: tornar-se cada vez mais ela mesma (ou o que Silva Freire pensava ser a cidade) ao abraçar uma suposta essência regional enfatizada pelo autor em outras publicações sobre o carnaval cuiabano, em especial em um artigo de título bastante sugestivo: "Raízes da raça” (FREIRE, 1986, p. 237).

Ainda na recolha de memórias carnavalescas, Freire dedica porção significativa da seção da Trilogia ora em análise à reprodução de trechos de marchinhas do carnaval da década de 20. Como pierrô que caminhasse na Quarta-Feira de Cinzas entre os restos do folguedo, apanhando aqui e ali restos de fantasias, adereços e serpentinas, o poeta faz um apanhado de estrofes avulsas das canções do carnaval cuiabano de rua. Entre estas, a diagramação de Dias-Pino acaba por enfatizar uma, impressa em página separada das demais (Figura 5), contornada por ilustrações maiores e mais trabalhadas; trata-se da marchinha "O democrata", do bloco Mé Coado, um dos mais antigos da capital do estado, já com expressiva adesão popular no início do século XX. 


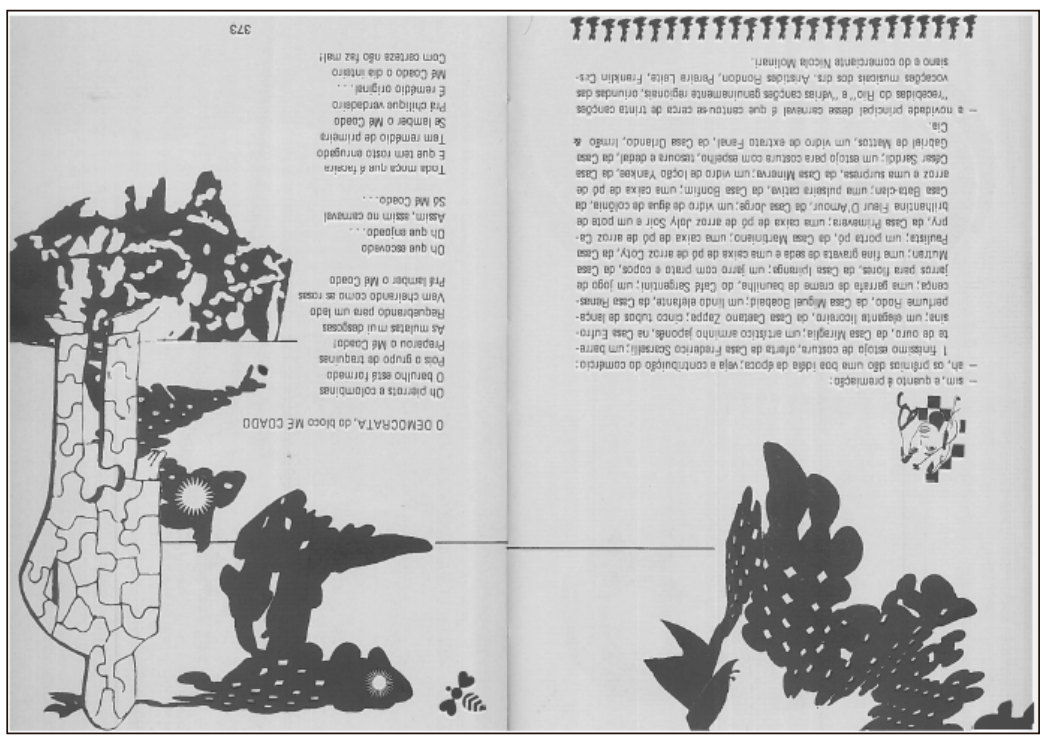

A edição e a

diagramação

da Trilogia

Cuiabana

como álbum

de recortes:

um exercício

relacional da

memória

Figura 5: Diagramação da página com a letra da marchinha "O democrata"

Fonte: Freire (1991b, p.373)

Como tantas outras marchinhas de carnaval, a letra da canção é repleta de duplos sentidos, com alusão ao álcool e erotismo, como nos versos "Tem remédio de primeira/se lamber o Mé Coado" e "Mé Coado o dia inteiro/Com certeza não faz mal". Os foliões que brincam essa folia são nomeados na marchinha como "grupo de traquinas", formado por "pierrots", "colombinas", e "mulatas mui desgosas" (sic).

Por sua vez, ilustração e diagramação ampliam os sentidos da marchinha, por meio de diferentes elementos pictóricos que se observam nas páginas representadas na Figura 5. Nas partes inferior e superior das páginas, notam-se linhas horizontais, característica do estilo de Dias-Pino, presente em toda a Trilogia Cuiabana e em outros livros por ele editados, definindo espacialidades e áreas visualmente distintas nas folhas de cada volume.

Note-se que a linha inferior da página esquerda é estilizada, formada por uma diminuta gravura de coelho repetida 26 vezes, em possível alusão ao acelerado ritmo reprodutivo desses animais - metáfora do erotismo carnavalesco? - ou à Páscoa, feriado cristão indissociável do profano carnaval. Já as linhas horizontais superiores quase estabelecem uma reta perfeita unindo as duas páginas; no entanto, como se tivessem tomado o "Mé Coado" e entrassem em estado etílico (tema recorrente em outras seções da Trilogia Cuiabana, como no longo poema "Os boêmios"), essas linhas "tropeçam" na costura entre as páginas, criando um ruído visual. 
O traçado de linhas em torno do texto da marchinha e a adição de gravuras desconexas entre si, como o diminuto rosto estilizado de mulher, na página da esquerda, e as imagens mais abstratas nas partes superiores e à direita, caracterizam a linguagem visual de álbuns de recortes. Nesse suporte, é muito comum que as inscrições e colagens de uma mesma página se deem em tempos distintos. Pode-se hoje colar uma foto; amanhã, contornar à nanquim essa imagem; daqui a um ano afixar ao lado um poema com clipe ou grampo. Esse projeto sempre adiado e nunca completo, que faz de todo álbum um palimpsesto, comparece, portanto,

Vinícius

Pereira nessas páginas da Trilogia Cuiabana, mas também em todo o restante da obra. Antoine Compagnon, refletindo sobre os diferentes tempos das operações de escrever, ler, citar, copiar, cortar etc. na interação com o texto, diz-nos poeticamente do que seja a bricolagem intertextual, muito próxima do que Dias-Pino fez na organização da Trilogia:

Gosto do segundo tempo da escrita, quando recorto, junto e recomponho. Antes ler, depois escrever: momentos de puro prazer preservado. Será que eu não preferiria recortar as páginas e colá-las num outro lugar, em desordem, misturando de qualquer jeito? Será que o sentido do que leio, do que escrevo tem uma real importância para mim? Ou não seria antes uma coisa que procuro e que me é, às vezes, proporcionada por acaso, por estas atividades: a alegria da bricolagem, o prazer nostálgico do jogo de criança? (COMPAGNON, 1996, p. 11-12)

Nesse excerto, bem como em todo o livro 0 trabalho da citação (1996), Compagnon toma o recortar e o colar como metáforas para uma ação que não é propriamente a de cindir ou unir, mas sim a de grafar: trata-se de formas de compreender o processo de escrever, como sublinha a expressão "segundo tempo da escrita". E é justamente como um segundo tempo da escrita, isto é, como um grafismo adiado em relação à primeira escrita (a de Silva Freire), que Dias-Pino diagrama e edita a Trilogia Cuiabana. Nessa atividade editorial, recortar e colar são também metáforas para um processo que é, sobretudo, o do grafismo.

Sob tal perspectiva, podemos ler as imagens da parte superior e à direita da Figura 5 como representações gráficas de cortes. Observem-se, por exemplo, as figuras negras unidas pelas retas na parte superior das referidas páginas: se, do ponto de vista do referente, podem representar 
de maneira abstrata algumas das personagens humanas da marchinha (como um casal de colombina e pierrô), sua estética de formas vazadas sugere um molde escavado e carimbado na página, ressaltando os cortes não pintados em meio à mancha preta. A possível identificação de duas cabeças que se olham de frente nessas imagens amplifica também a associação com a letra da marchinha, justificada pela clara representação de uma abelha (produtora de mel, ou "mé" coado) pela mesma técnica gráfica, junto à figura da direita. Ademais, aludindo graficamente às noções de corte, colagem e montagem, ganha ainda destaque a ilustração mais claramente antropomórfica da página da direita: o homem formado por um quebra-cabeça, isto é, pela juntura de partes desconexas em um todo visual, como álbum que colige os fragmentos de carnaval.

Essa montagem polifônica de diferentes discursos - conceito A edição e a diagramação da Trilogia Cuiabana como álbum de recortes: um exercício relacional da memória que, na teoria bakhtiniana, aproxima-se da paródia e do próprio conceito de carnavalização (BAKHTIN, 2010) - revela-se de maneira ainda mais evidente na Trilogia Cuiabana quando Dias-Pino diagrama imagens visualmente mais carregadas do álbum de recortes, como na Figura 6.

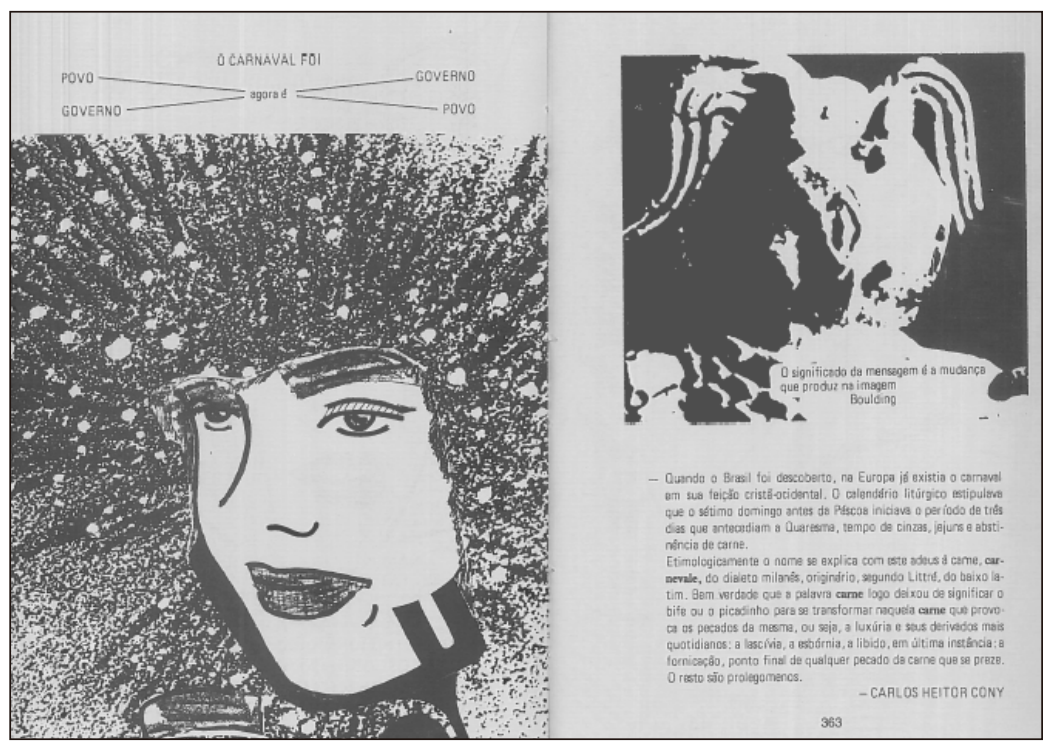

Figura 6: Diagramação das páginas 362 e 363 da Trilogia Cuiabana.

Fonte: Freire (1991b, p. 362-363)

Nesse par de páginas, o leitor se defronta, em uma só mirada, com um poema visual de Silva-Freire, um desenho de Wlademir Dias-Pino, uma gravura de difícil interpretação, um aforisma de Kenneth Boulding 
(teórico da imagem) e um excerto de Carlos Heitor Cony. Não há nenhuma explicação verbal para a relação entre esses textos, cabendo ao leitor interpretar os princípios associativos que presidiram à sua justaposição.

Tanto pelo tamanho, quanto pela atração que toda imagem impõe aos olhos, o leitor, diante dessas páginas, é logo atraído pelo desenho da página da esquerda, que representa uma figura feminina segundo o estilo pictórico de Dias-Pino (perfil em três-quartos e lábios carnudos, conforme já visto na Figura 4). Uma textura com efeito de giz de cera envolve o rosto da moça, destacando-lhe, por oposição à profusão de traços do

Vinícius

Pereira contorno, o semblante de poucas linhas. Além disso, a textura formada por traços que parecem partir de um mesmo ponto zero - oculto atrás do rosto feminino - ganha nova significação se compreendida no contexto de carnaval, explicitado no poema de Silva Freire, logo acima, e no texto de Carlos Heitor Cony, ao lado. Contíguo a esses fragmentos, o desenho é ressemantizado, e a textura a giz de cera ganha significação mais precisa: torna-se portentoso adereço de cabeça, com plumas e penas que partem em todas as direções, como parte de uma fantasia de carnaval.

A beleza da moça desenhada e o esplendor das penas que lhe adornam o rosto dialogam diretamente com o texto da parte inferior da página da direita, em que Carlos Heitor Cony discorre brevemente sobre a origem europeia do carnaval, sua relação com a Páscoa e sua etimologia como "adeus à carne" - objeto de desejo alimentar e sexual -, no período quaresmal de abnegação. Em sua exposição, a relação entre carnaval e prazer carnal ganha destaque, como se nota no fragmento a seguir:

\footnotetext{
Bem verdade que a palavra carne logo deixou de significar o bife ou o picadinho para se transformar naquela carne que provoca os pecados da mesma, ou seja, a luxúria e seus derivados mais quotidianos: a lascívia, a esbórnia, a libido, em última instância: a fornicação, ponto final de qualquer pecado da carne que se preze. $O$ resto são prolegômenos. (CONY apud FREIRE, 1991b, p. 363 , grifos do autor)
}

Já no canto superior esquerdo da Figura 6, o lacônico poema de Silva Freire define o tríduo momesco por meio de outros recursos retóricos, que não a apoteose da carne. 0 poeta delineia o cruzamento de duas oposições binárias que balizariam o carnaval: o eixo passado-presente ("foi" x "agora é”) e o eixo povo-governo. Tal estrutura é reforçada no plano visual por 
um expediente gráfico recorrente nos poemas visuais do autor: o uso de linhas retas diagonais cruzadas ao centro do texto, criando um quiasma que reforça a dialética "povo" x "governo". Também aludindo ao fundamento histórico do carnaval - tempo de subversão hierárquica, em que o pobre se fantasia de rei e o rico se disfarça de trapos -, o poema transcende o informativo para fazer-se espaço estético de crítica social, ao sugerir que hoje o governo se coloca acima do povo, não só no transcorrer cotidiano da política, mas também no tempo de exceção do carnaval.

Além disso, a alternância entre formas verbais do verbo "ser" no pretérito perfeito e no presente do indicativo coloca em questão não só o hoje e o ontem do tempo de escrita de Freire. Na Trilogia Cuiabana, o "foi" e o "é" do carnaval ganham diferentes dimensões, a depender se tomarmos como referência o tempo de enunciação do eu-lírico freireaA edição e a diagramação da Trilogia Cuiabana como álbum de recortes: um exercício relacional da memória no, da diagramação de Dias-Pino, ou da leitura da obra hoje, como nas diferentes camadas de fragmentos que se vão sobrepondo, ao longo do tempo, em qualquer álbum.

Realizando diferentes pontes entre carnavais de temporalidades disjuntas, esses textos acabam por estabelecer também diferentes conexões entre si, graças à diagramação que os justapôs. Nesse sentido, faz-se metassigno desse par de páginas, mas também de toda a edição da Trilogia Cuiabana, o aforisma de Boulding: "O significado da mensagem é a mudança que produz na imagem". Cada um dos fragmentos memorialísticos do carnaval nessa seção - tal qual cada um dos fragmentos de lembranças de Cuiabá na Trilogia como um todo - pode ser entendido como uma mensagem em si, mas de sentido lacunar, porque sempre recortado do real para ser colado num álbum de memórias editado e diagramado por Dias-Pino. É, pois, só no dialogismo entre esses fragmentos, cuja justaposição e superposição é ensejada pelo álbum, como coleção de discursos, que se podem entender de forma holística as imagens do antigo carnaval cuiabano - metonímia de toda a Cuiabá de antanho, buscada por Silva Freire e reeditada pelo organizador da Trilogia Cuiabana. Feito a ilustração em que Dias-Pino posicionou a citação de Boulding, de contornos discerníveis, mas não identificáveis com precisão, as memórias que a Trilogia exibe, como coleção, permanecem para sempre num chiaroscuro entre o factual e o imaginário, o pessoal e o coletivo, a memória e a rememoração. Trata-se, enfim, de álbum de recortes e colagens composto por quatro mãos, as quais operaram tesoura e cola em tempos distintos, mas sempre em ato relacional. 


\section{Considerações finais}

Silva Freire escreveu três livros de poemas; Wlademir Dias-Pino diagramou/editou dois poéticos álbuns de recortes. Na interação entre esses movimentos complementares, veio a público a incompleta Trilogia Cuiabana, em cujos dois volumes observa-se um cuidadoso trabalho de memórias pessoais e coletivas da Cuiabá da primeira metade do século XX.

Nessa obra, torna-se ainda mais significativo o estilo paratático de Freire, com blocos ordenados sem uma progressão temática clara, os

Vinícius

Pereira quais podem ser percorridos em ordem definida pelo próprio leitor. Tal textualização por fragmentos justapostos materializa, na escrita, a dinâmica de associação livre em que se estruturam as memórias de um sujeito. Estas não se desenrolam segundo um programa teleológico, com começo, meio e fim, urdidos pelos princípios da coerência discursiva; esta se lhes é imposta a posteriori no ato narrativo que visa a recordar. Em si mesmas, as reminiscências se agrupam em um processo que só o inconsciente concebe, repleto de sobreposições, contradições e lacunas, as quais enevoam o que há de factual para ser lembrado.

No caso da Trilogia Cuiabana, porém, a interação entre escrita e memória é ainda mais complexa - talvez, motivo pelo qual essa seja uma obra ainda pouco estudada na literatura mato-grossense do século $\mathrm{XX}$-, visto que é atravessada por um segundo movimento discursivo: a diagramação/edição de Dias-Pino.

Se, na leitura de livros de poemas, não é comum considerar a dimensão editorial, tal abordagem seria impraticável na Trilogia. A participação de Dias-Pino, mais do que simplesmente transpor os originais para um formato publicável pelas máquinas da editora da UFMT, implicou uma reinterpretação das memórias de Silva Freire ou mesmo uma rememoração das lembranças partilhadas com esse amigo, fosse na vida em comum em Cuiabá, fosse nos diálogos sobre o passado da capital mato-grossense.

Dos paratextos como capa, contracapa, lombada, orelha ou prefácio, ao miolo dos volumes, permeados por fotos, citações, desenhos e fragmentos de jornais, os poemas de Freire foram incorporados a um suporte outro: foram feitos objetos de coleção, junto a outros fragmentos de memória, em dois poéticos álbuns com a memória de Cuiabá. Nestes, resta patente o afeto que permeou a amizade de ambos os artistas por várias décadas, estampada nas páginas de uma obra em que cada poema 
é acompanhado de uma resposta visual do editor, o qual procedeu como se colasse, aos cantos e quinas de livros queridos, mementos de um tempo que passou, mas que se quer para sempre preservar do olvido.

Nesse caso, a mudança de gênero discursivo implicou a edição de uma obra amplamente intertextual, que tenta dar conta de uma visão multiperspectivada da Cuiabá da primeira metade do século XX. Há, pois, em praticamente todas as páginas da Trilogia Cuiabana, um gesto gráfico de Dias-Pino, interagindo por meio de imagens desenhadas, fotografadas ou gravadas, com as reminiscências poéticas de Freire. Assim, o mosaico que acaba por se formar com as imagens da cidade, colorido como o carnaval de que tanto a obra fala, tenta recompor o que fora Cuiabá, ganhando especial sentido para aqueles que hoje leem a Trilogia como quem folheia um álbum de memórias, em busca de ser assomado por flashes de A edição e a diagramação da Trilogia Cuiabana como álbum de recortes: um exercício relacional da memória um tempo outro na cidade que tanto encantou Silva Freire e Dias-Pino.

Nessa dinâmica intertextual, os fragmentos poéticos da Trilogia Cuiabana se aproximam ainda mais do caráter memorialístico que os une. Afinal, toda memória é também uma extração do evento de sua espaciotemporalidade no mundo, a fim de reelaborá-lo como língua e como subjetividade, atando o nó entre real, simbólico e imaginário de que se fazem os sujeitos e suas reminiscências. ${ }^{8}$

\section{REFERÊNCIAS}

BAKHTIN, M. Problemas da poética de Dostoiévski. Rio de Janeiro: Forense Universitária, 2010.

BENJAMIN, W. Passagens. Belo Horizonte: Editora UFMG, 2007.

CEIA, C. E-dicionário de termos literários. Disponível em <http:// edtl.fcsh.unl.pt/business-directory/6588/album/>. Acesso em: 17 out. 2017.

COMPAGNON, A. O trabalho da citação. Belo Horizonte: Editora UFMG, 1996.

FREIRE, S. )na moldura da lembrança(. Cuiabá: UFMT, $1991 b$.

80 autor do presente artigo agradece à Fundação de Amparo à Pesquisa do Estado de Mato Grosso (FAPEMAT) pelo apoio à execução desta pesquisa. 
)presença na audiência do tempo(. Cuiabá: UFMT, 1991a.

. Silva Freire: social, criativo, didático - catálogo de exposição. Cuiabá: Imprensa Universitária, 1986.

GENETTE, G. Palimpsestos: a literatura de segunda mão. Belo Horizonte: FALE/UFMG, 2006.

LACAN, J. Seminário R. S. I. (inédito), 1974-1975.

Vinícius

Pereira

MAGALHÃES, E. de M. Por entre brenhas, picadas a foice, matas bravas: a produção poética em Mato Grosso no século XX e XXI. 120 Tese de Doutorado. Programa de Pós-Graduação em Letras, da Universidade Católica do Rio Grande do Sul. São Paulo, 2014.

MAGALHÃES, H. G. História da literatura de Mato Grosso: século XX. Cuiabá: Unicem, 2001.

RAMOS, I. N. A. R. Vanguardas poéticas em permanência: a revalidação de Wlademir Dias-Pino e Silva Freire. Tese de Doutorado. Programa de Pós-Graduação em Estudos Comparados de Literaturas de Língua Portuguesa, da Universidade de São Paulo. São Paulo, 2011.

RIBEIRO, M. Planejamento visual gráfico. Brasília: L.G.E, 2003.

SONTAG, S. On Photography. New York: Rosetta Books, 2005.

Recebido em fevereiro de 2018

Aceito em abril de 2018 